\title{
CONTRIBUTION OF WOLDEMAR VON KNIERIEM TO THE TRAINING AND EXPERIMENTAL FARM «PETERHOF» OF RIGA POLYTECHNICUM AND RIGA POLYTECHNIC INSTITUTE
}

\section{SVETLANA KOVAḶČUKA* \\ University of Latvia}

Summary. The article is dedicated to Professor Woldemar von Knieriem (18491935), who has made a significant contribution to the development of agricultural science, headed the Department of Agriculture of Riga Polytechnic Institute (1903-1906), as well as Training and Experimental Farm «Peterhof» (18801915) near Olaine city. It became a model farm not only in the Baltic region but also throughout the Russian Empire. Professor W. von Knieriem was the Director of RPI (1906-1916), an outstanding organizer and author of scientific works. He provided students with extensive theoretical and practical knowledge in agriculture, focusing on practical, scientifically approbated lessons about the management of agricultural land and manors and trying to raise the general level of culture and the horizons of young people. Professor W. von Knieriem was Rector of the Baltic Technical University in Riga (1918) and worked in the Herder Institute in Riga (1920-1927). He spent his last years in his family estate in Livonia writing memories of his life and enjoying the company of grandchildren - one of them later became Prime Minister of Sweden Ulof Palme (1927-1986). W. von Knieriem died in January 1935 and was buried in the Great Cemetery in Riga.

Keywords: Woldemar von Kieriem, Training and Experimental Farm «Peterhof», Riga Polytechnic Institute, agriculture.

* Corresponding author.

E-mail: sv.kovalchuk@gmail.com 


\section{First Years of Operation of Department of Agriculture of RP}

Department of Agriculture was established in 1863 [1]. In first years of operation it did not have its own land for practical tests and future agronomists were educated more in technology and chemistry than in agriculture. The first graduates had studied for two years, while Professor Carl Hehn (1821-1875) began working at RP and reworked the study programme for a three-year course in 1868, reducing the number of subjects not directly related to agriculture and increasing special ones. C. Hehn became the first Dean of the Department (1869-1873) and began teaching agriculture, meadow farming, crop production, gardening, forestry, etc. paying attention also to local conditions [2]. In 1873, geodesist Anton Schell (1835-1909) became Dean of the Department of Agriculture and was also Dean of the Department of Surveying. Professor C. Hehn went to work to Tartu. The situation improved in study year 1874/1875 when Professor Jegor von Sivers (1823-1879) took over the agricultural professorate.

J. von Sivers was the Dean of the Department of Agriculture (18741879) of RP. Since the beginning of his employment, practical training of RP students took place in Pārdaugava, Zasulauks manor owned by RP co-founder Adolph Thilo (1817-1887). There was free land in the centre of Riga, near 19 Tronmantinieka (at present - Raina) bulvāris, but at the time the city construction took place there and neither the botanical garden nor experimental fields planned by the professors were established there. The Dean of the Department, Professor J. von Sivers, who was known as a successful manor manager, drainage specialist, but most of all as a tireless traveller, poet, cultural historian, actively supported the idea about the need to establishing an agricultural testing base. In June 1876, Konstantin Engelhardt (1855-?) from Smolensk and Johann Friedrich Anselm (1859-?) from Odessa, graduates of the Department of Agriculture headed by Professor J. von Sivers, donated 1000 rubles each to the establishment of an agricultural test station [3].

RP Council appealed to the Ministry of Domains with a request to allocate land for the establishment of an agricultural test station near Riga. On $25^{1}$ April 1877, the Order of State Property was issued in St. Petersburg and supported by Livonia Governor - RP Curator Baron Alexander von Üxküll Gyldenbandt (1840-1912), and Minister of State Property Pyotr Valuyev (Пётр Валу́ев; 1815-1890) permitting to use the territory of land of 278 hectares of farm «Peterhof», located 24 miles from Riga, near Olaine (at present - Pēternieki, village in Olaine parish), for educational purposes without reward for 24 years. The Ministry of

\footnotetext{
${ }^{1}$ In article, the dates are listed after the July calendar or in old style.
} 
State Property refused to support «Peterhof», so a significant part of the manor had to be rented. Within two years of hiring, it was hoped to get resources to build a test farm where students could practice.

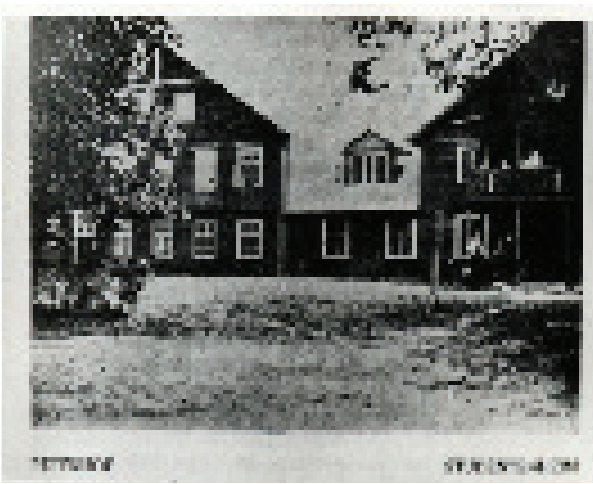

Figure 1. «Peterhof» (beginning of the 20th century) [4].

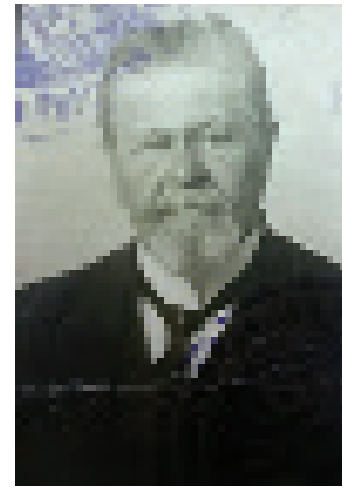

Figure 2. W. von Knieriem (around 1920) [5].

Due to the sudden death of J. von Sivers in April 1879, the development plans for the training and trial farm were halted until Professor Doctor of Philosophy and Economics Woldemar von Knieriem was invited from the University of Tartu.

\section{The Work of W. von Knieriem at Training and Experimental Farm «Peterhof» and RP}

W. von Knieriem was born in Mürmuiža, Kauguri parish [5], studied law and economics at the University of Tartu and obtained a doctoral degree in economics (1877). He graduated from the University of Heidelberg from where he obtained his doctoral degree in philosophy (1872). W. von Knieriem became a state advisor, was the Dean of the Department of Agriculture (1903-1906) and headed the Training and Experimental Farm «Peterhof» (1880-1915). He did not leave the job at «Peterhof» even when he was elected a Director ${ }^{2}$ of RPI in 1906 [6]. Due to the growing number of students the Professor needed help in managing the farm «Peterhof». From 1895 to 1898, von Knieriem was assisted by his wife's father, an experienced farm manager Ottokar Kupffer (1829-1901), who worked as a farm manager at «Peterhof» and held the position of maintenance manager of the Department of Agriculture of RP and RPI and was also assistant to W. von Knieriem (study year 1897/1898) [7]. For many years (1886-1902), W. von Knieriem was a subordinate to Dean of

\footnotetext{
${ }^{2}$ Until September 1917, the Rector of RPI was called Director.
} 
the Department of Agriculture Professor Georg Thoms (1843-1902), who ran the pilot station where agrochemical analyses were conducted.

W. von Knieriem was of the opinion that university education meant not just mastering specialized subjects. Students were offered various courses in economics, natural sciences and history, legal and technical sciences. Students also had to study mechanical engineering, drawing, construction, chemical technology, politics, etc. The Farm invited lecturers from other departments, including professors. The reorganization of the Training and Experimental Farm «Peterhof» began in 1881. Funds for construction of the building were partly provided by the government, partly by the RPI Council [8].

In 1882, Professor W. von Knieriem moved the chemical laboratory to «Peterhof». He lectured not only on chemistry, as well as on crop production, meadow farming and livestock farming. In study year 1864/1865, there were eight students in the department, in 1881/1882 - it was already 48 young people, whereas in 1892/1893, the number of students increased to 140 [9]. Over a hundred students from the inner provinces of the Russian Empire: Kovno, Pskov, Vitebsk, Vilnius and other provinces, came to Riga to study [10].

Professor W. von Knieriem was an honoured teacher. In his pedagogical work, he was following the standards of the private gymnasium Bērzaine, where he himself was educated. Albert Woldemar Hollander (1796-1868), head of the gymnasium and his associates followed the theory of Swiss teacher Johann Heinrich Pestalozzi (1746-1827) and his pedagogical methods were also used by W. von Knieriem, for example, the principle of succession in learning, love of work, use of scientific knowledge in practice, etc. Like Pestalozzi, W. von Knieriem spent a lot of time with his students, discussed current events, shared the table during meals [11].

Professor W. von Knieriem in his German and Russian publications [12; 13] reiterated that he could develop curricula at his own discretion across the farm, as the main objective was to provide students with a comprehensive range of theoretical and practical knowledge in agriculture, linking theory with practical skills as much as possible; to nurture students' ability to manage farms qualitatively. W. von Knieriem was glad that he did not have to work with students only in auditoriums. The study process was designed so that students would have the opportunity to acquire theoretical knowledge in the Department of Agriculture in Riga for 2.5 years and to live in «Peterhof» for one year to acquire practical skills. Sometimes students stayed in the manor for over a year. Every week, four duty attendants were appointed to «Peterhof» who were on duty from dawn to dusk: working in the field, with a horses in the rack, looking after pigs and cows, or working in the grain store. On Sundays,
Woldemar von

Knieriem to the

Training and

Experimental Farm

«Peterhof» of Riga

Polytechnicum and

Riga Polytechnic

Institute 
they reported to Professor W. von Knieriem about the work progress during the week, the feeding of animals, the quality and quantity of milk that was delivered and the use of milk. By the way, milk from the manor was taken to Riga for sale.

Particular attention was paid to those students who were writing diploma papers. The final exam consisted of three written works: in natural sciences, i. e. the graduate independently conducted and described experiments with fertilizers or animal feeding; the graduate drew up a plan and a full assessment of the agricultural structure; the graduate described in detail the real (or imagined) manor. To assure the quality of diploma papers, the management of the Farm constantly took care of the modernization and improvement of the chemistry laboratory.

Professor carefully and tirelessly familiarized the students with his walks, ran improvised musical evenings in which he usually played with someone sonatas of $\mathrm{L}$. van Beethoven. W. von Knieriem also took care of the students in the «Peterhof» common dining room, advised and took an active part in future planning. In his memoirs, W. von Knieriem sincerely described the atmosphere of colloquiums, defence of diploma works which were attended by ex-graduates and owners of neighbouring manors. The defence took place in a friendly atmosphere that ended with an informal evening. Each graduate had to submit a diploma paper in two copies, one of which remained in the archive of «Peterhof». The quality of gained knowledge was high, graduates worked in ministries and took administrative positions in Riga and St. Petersburg [14]. Later, in the 1920s and 1930s, many graduates of the Department of Agriculture worked in various ministries of the Republic of Latvia.

\section{The Work of W. von Knieriem at Training and Experimental Farm «Peterhof» and RPI}

In the second half of the 1880s, the Russian Empire began to change its language policy, which was directly related to the University of Tartu and RP. By the Regulation of 29 September 1892, the government required to introduce the training in Russian. The discussions began between representatives of the Ministry of National Enlightenment and RP. Some of the study courses were changed into Russian, the teaching staff could continue teaching in German [15]. There were significant changes in the life of the university in 1896 - RP was reorganized into an institute with rights and duties of other similar technical training institutions in Russia. The duration of the training was extended to four years, the duration of the students' studies at «Peterhof» was extended to three semesters. 
The diploma exam was based on two theses: manor organization plan and scientific work in agricultural and nature studies.

The expansion of the program of Department of Agriculture as well as the introduction of special subjects required specialists from other,

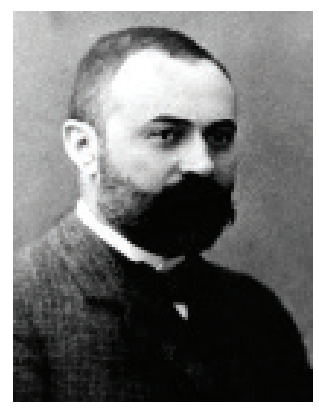

Figure 3. Fyodor Buholch

(beginning of the 20th century) [16].

new profiles. For example, RPI graduate biologist Fyodor Buholch (Федор Бухгольщ; 1872-1924) who soon became an Adjunct Professor (1903), Professor (1907) and Vice-Director of RPI (1910-1913), began to work at the Moscow University on 1 January 1898; later, in February 1912, he became Dean of the Department of Agriculture (1912-1918) [17].

This truly gifted young scientist was pleased to work with Professor W. von Knieriem as his colleague and co-author. Later on, Buholch edited «Известия и труды сельско-хозяйственного отделения Рижского Политехнического института» («News and Works of the Deparment of Agriculture of RPI»), 1914-1917. Along with his pedagogical work, F. Buholch conducted significant research and was one of the most prominent mycologists of the Russian Empire in the early 20th century and the founder of mycology in Latvia [18].

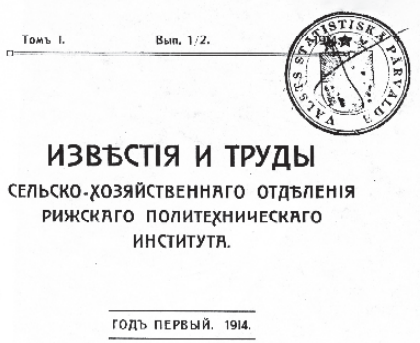

Figure 4. Buholch, F. Известия $и$ труды сельско-хозяйственного Rapports et travaux de la section agronomique de I'lnstitut Polytechnique à Riga. Vol. 1, lior. 1:2. Année 1914. отделения Рижского Политехнического института» («News and Works of the Department of Agriculture of RPI»), 1914-1917 [19].

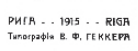

\section{(19)}


22 October 1899 was an important date for RPI was on - state property «Peterhof» with its land, horse stables, forestry and laboratories became part of RPI. In 1900, the Department of Agriculture were given new premises in the new building at 4 Puškina (at present Kronvalda) bulvāris in Riga.

When describing W. von Knieriem contribution to scientific research in RP and RPI Training and Experimentation Farm «Peterhof», calendar «Landwirtschaftlicher Kalender für Liv-, Est- und Kurland» («Agricultural Calendar for Livonia, Estonia and Courland») compiled by him, which was published for 20 years (1894-1913), has to be mentioned. Agricultural Calendar (1900-1914) was published also in Russian under the title «Сельско-хозяйственный календарь» («Agricultural Calendar»). The author, Professor W. von Knieriem, later wrote in his memoirs that since the agricultural calendar in Russian was published in 1900, RPI's name had been mentioned far beyond the borders of the Baltic provinces [20].

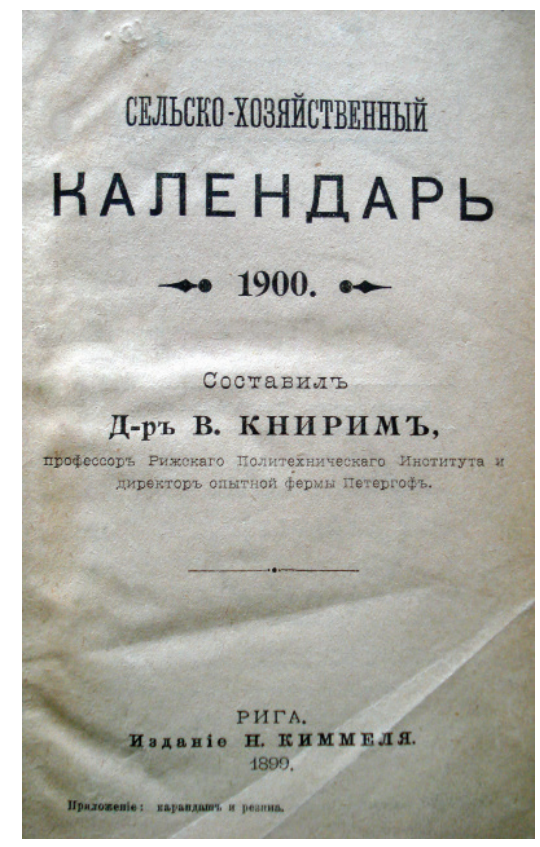

Figure 5. Title page of the Agricultural Calendar 1911 (in Russian), compiled by W. von Knieriem (1910) [21].

During the reign (1894-1917) of the emperor of Russia Nicholas II, Nicholas Romanov (Николай II Александрович Романов; 1868-1918), great attention was paid to education, especially to agricultural education. In many Russian universities, departments of agriculture were opened [22], the number of educational institutions and their maintenance costs increased. On 26 May 1904, the «Regulation on Agricultural Education and its Application» was approved [23]. Attention was also paid to 
RP and RPI Training and Experimental Farm «Peterhof»; in 1906, a new brick building was built, which was convenient for students to live there. At the beginning of the 20th century, the Treasury allocated 22000 rubles for feeding animals kept in «Peterhof» [24]. In June 1906, Jelgava Forestry divided about 1300 dessiatins $^{3}$ of large forest to «Peterhof», so that the it could continue education [25]. Preparations for the establishment of the Department of Forestry began and it was planned to open it on 1 September 1915.

Thanks to Professor W. von Knieriem's scientific endeavours, experiments with soil fertilization, the effects of phosphates on various soils, fertilization of clover and meadow, soil fertilization experiments with cultivated plants and animal feed for dairy cattle and cattle have been carried out since 1881. Milk, animals (bulls, calves), etc. were sold. By the end of the 1890s, the «Peterhof» farm also regularly received benefits from the St. Petersburg Main Agricultural Office, the Livonia Department of Agriculture and the Ministry of National Enlightenment, which undoubtedly contributed to scientific research and the introduction of modern technologies and techniques. Priority areas were agrochemical experiments, scientific selection of cereals, flax seeds and, in particular, the creation of optimal rational feed for dairy cattle and cattle.

Examples of the growth and development of the training farm «Peterhof» are as follows: total area - 255 dessiatins (278 hectares) of poor soil; arable land and total area of meadows - 200 dessiatins (219 hectares). On 23 April 1881, the total income of the farm (existing equipment, non-working inventory, gross income from arable crops, meadows, building costs) was 32428 rubbles, on 23 April 1897 83888 rubles; on 23 April 1910 - 182411 rubles.

Direct income from the farm increased steadily: from 1880/1881 to 1889/1890, income was 5844 rubles and 1 kopeck; from 1900/1911 to 1909/1910, the revenue amounted to 12381 rubles and 36 kopecks [26].

Employees of «Peterhof» maintained close scientific contacts with colleagues from Western Europe and Russia. This is evidenced by the scientific publications and conferences in which they participated. Scientific contacts were maintained with the University of Tartu, Kharkiv University, Moscow Agricultural Institute ${ }^{4}$, the New Alexandria Academy of Agriculture and Forestry in the Province of Lublin ${ }^{5}$, I. Stebut High

\footnotetext{
${ }^{3}$ Russian: десятина; an archaic land measurement used in tsarist Russia. A dessiatin is approximately equivalent to 2.702 English acres or 10,925 square metres.

${ }^{4}$ Moscow Agricultural Institute was founded on 6 June 1844 in the manor of PetrovskoRazumovska. The aim of the institute was to provide students with university education in agriculture and agricultural science.

${ }^{5}$ New Alexandria Academy of Agriculture and Forestry was founded in 1816 and it became one of the first higher agricultural educational establishments in Europe and Russia. At the beginning it was located in Warsaw.
}

Contribution of Woldemar von Knieriem to the Training and Experimental Farm «Peterhof» of Riga Polytechnicum and Riga Polytechnic Institute 
Agricultural Courses ${ }^{6}$ for Women in St. Petersburg and the Caucasus training area. The lecturers of the department attended conferences, went on visits and exchanged experience with personnel of agricultural stations in the Baltic region, participated in agricultural exhibitions in Germany, Denmark, Sweden, Silesia, Breslau (at present - Wroclaw) [27].

In January 1912, the first year-long courses on the re-cultivation of marshes and the cultivation of meadows began in «Peterhof». For this purpose, a large bog of 173 dessetians (189 hectares) was granted. Persons with university education in agriculture enrolled in courses.

«Peterhof» became the leading farm not only in the Baltic region, but also in the whole Russian Empire. Professor W. von Knieriem had a extensive experience and he felt that such a farm should be an independent agricultural organization and students should always see the farm as a whole, understanding the relationship between the different sectors of the economy [28].

On 27 May 1913, regular final exams were held. The Examination Commission was chaired by Professor W. von Knieriem. Out of the 19 students, 17 took the final examination. As a result, 13 students received a first-class agronomy diploma and four - a second-class diploma. Each graduate conducted and scientifically substantiated a practical work (animal feeding, soil fertilization, etc.) and defended a diploma paper on organizing a farm (real or imaginary), taking into consideration climatic conditions and soil quality in the provinces ${ }^{7}$ of Courland, Livonia, area of Don Kazaks, Vilnius, Vitebsk, Kaunas, Pskov, Saratov and Minsk. For example, Sergei Witowski (Сергей Витовский; 1888-?) described and scientifically substantiated the experience of feeding cows with protein-deprived feed and presented the work «Farm «N» in the province of Livonia». Erik von Bremen (1888-1963) carried out research «On Experience of Feeding hay Lathyrus pratensis to Milk Cows» and submitted to the Examination Commission work «Organization of Farm «L» in the Province of Estonia». Pavel Kolekovsky (Павел Коллековский; 1880-1930), one of the graduates of the Department of Agriculture (1915), who was awarded the agronomist diploma of first category, presented two papers: «Experience in clover fertilization» and «The organization of farm «I» in the province of Kiev». His fellow student Péteris Konrāds (1890-1966) presented on the scientific work «Experience in fertilizing mire soil with mineral fertilizers» and «Organization of farm «Gl» in the province of Petrograd» [29].

${ }^{6}$ On 21 September 1904, new High Agricultural Courses for women were founded in St. Petersburg. The initiator of the idea was scientist Professor Ivan Stebut (Иван Стебут; 1833-1923).

${ }^{7}$ On 1 January 1913, the total number of students in the Department of Agriculture was 332 persons. 270 students were from the Baltic provinces, the rest were from Kaunas, Vitebsk, Vilnius, Petrograd, Perm, Pskov, Bessarabia, Podolsk and other provinces, including the Caucasus and Central Asia. On 1 January 1914, the number of students was 375 . 


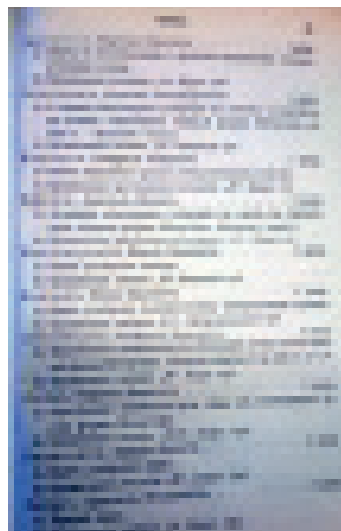

Woldemar von

Knieriem to the

Training and

Experimental Farm

«Peterhof» of Riga

Polytechnicum and

Riga Polytechnic

Figure 6. Topics of Diploma Papers of graduates of the Department of Agriculture of RPI, fragment (1915) [30].

The RPI Training and Experimental Farm «Peterhof» and the Department of Agriculture evolved and cherished various future plans, in realization of which the financial support from the state was of great importance. On 3 July 1914, the Russian Emperor Nicholas II signed the Law on allocation of 7000 rubles to the farm «Peterhof». The funding was to be used as follows: 1) 3000 rubles - for experiments on feeding of livestock and soil fertilization in the farm «Peterhof»; 2) 3000 rubles for publishing an agricultural edition; 3) 1000 rubles for inviting an expert to conduct experiments [30]. The allocated funding was used partly: from 1914 to 1916, scientific articles were published in the already mentioned edition «News and Works of the Department of Agriculture of RPI». The Department of Agriculture was the first who began the publication of scientific articles at RPI. In total, three volumes were published, divided into parts, totalling 12 editions. Chronicles, titles of students' diploma papers, scientific works of students and teachers, the reports on study and Experimental Farm «Peterhof» were published in these editions.

Figure 7. Title of the edition of scientific papers of the Department of Agriculture (1916) [31].

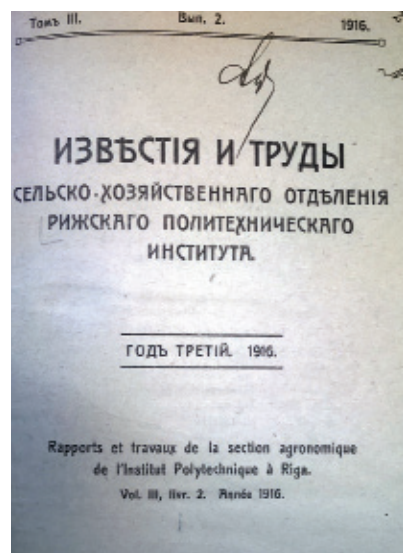




\section{Activities of W. von Knieriem at the End of His Life}

At the beginning of World War I, when the front was approaching Riga it hit «Peterhof» too, its inventory, cattle, documents, valuable large library, agricultural tools and machinery were destroyed in July 1915. Everything valuable was burnt because the evacuation was overdue. From the huge archive of «Peterhof» only two things have been preserved up to the present day - correspondence about its activities in 1912-1914 and the correspondence with the Main Administration of Agriculture on its forestry activities [32], as well as several personal files of teaching staff.

In August 1915, the RPI and its Department of Agriculture was first evacuated to Yuryev (the name of Tartu from 1893 to 1918), then to Moscow. In September 1915, 121 new students were enrolled in the department and on 1 January 1916, the number of students in the department increased to 373. The department was located at the premises of the Moscow Agricultural Institute, where the lessons - mostly theoretical continued until April 1918, when the RPI Training Committee decided to stop the Institute's work in Moscow and return to Riga. Then some of the lecturers and students moved to Ivanovovozensensk where the Ivanovovozensensk Polytechnic Institute started its work in autumn. Some of the lecturers and students returned to the German-occupied Riga [33].

Professor W. von Knieriem also evacuated to Russia and served as Director of RPI until 15 March 1916. Already on 24 December 1915, he was reprimanded for enrolment of persons subjected to military service, although there had been no regulation on restriction of student admission. Professor was dismissed from the post of Director and returned to Riga with his wife in the summer of 1917. In the autumn of 1918, the RPI was transformed into a Baltic Technical University, which only existed for three months and W. von Knieriem became its Rector. In 1919, he left to Germany and returned in 1920. From the autumn of 1920, Professor gave lectures at the Higher German Extramural Courses for agricultural professionals and from 1921 until retirement in 1927 worked at the Herder Institute.

On 11 May 1925, intellectuals of the capital of Latvia, public workers and graduates of the Department of Agriculture took part in the celebration of the 50th anniversary of Professor W. von Knieriem's pedagogical activity [34].

W. von Knieriem is one of the founders of agricultural science in Latvia. At the end of his life he lived in Livonia - Skangalsi Manor in Liepna parish, was engaged in agriculture, wrote about his life in «Meine Lebenserinnerungen» («My Life Memories») [35] and was happy to welcome guests, including his beloved grandchildren who lived in Sweden. One 
of his grandsons was the Swedish Prime Minister, Ulof Palme. Professor W. von Knieriem died on 14 January 1935. Unfortunately, the exact place of the grave in the Great Cemetery in Riga is not known.

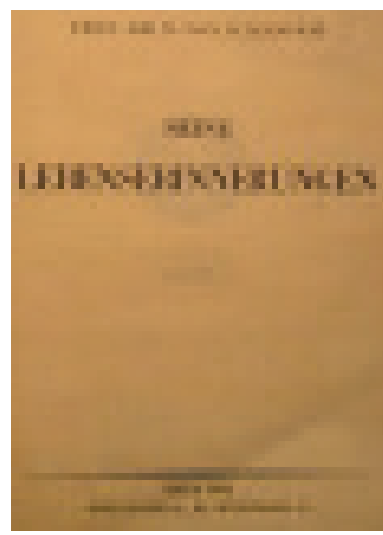

Figure 8. The title page of the memoirs written by W. von Knieriem on his life (1931) [35].
Contribution of Woldemar von Knieriem to the

Training and Experimental Farm «Peterhof» of Riga Polytechnicum and Riga Polytechnic Institute

\section{LIST OF SOURCES AND LITERATURE}

[1] Festschrift zum fuenfzigjaehrigen Jubilaeum des Rigaschen Polytechnischen Instituts 1862-1912. Riga: W. F. Haecker, 1912, S. VI.

[2] Augstākās tehniskās izglīin̄bas vēsture Latvijā. Rīgas Politehnikums. Rīgas Politehniskais institūts. 1862-1919. Rīga: RTU, 2002, 147. lpp.

[3] Knieriem, W. von, Bucholtz F. Die landwirtschaftliche Abteilung am Polytechnischen Institut zu Riga in den ersten 50 Jahren ihres Bestehens (1862-1912). Riga, 1915, S. 5.

[4] Knieriem, W., von. Meine Lebenserinnerungen. Riga: Plates, 1931, 15 S.

[5] Latvijas Nacionālā arhīva Latvijas Valsts vēstures arhīvs (turpmāk LNA LVVA) 2996. f., 10. apr., 32031. l., 1. lp.

[6] LNA LVVA 7175. f., 1. apr., 170. 1., .29., 147. lp.

[7] Sechsunddreissigster Rechenschaftsbericht des Verwaltungsraths des Rigaschen Polytechnischen Instituts für das Studienjahr 1896/97. Riga: Muellersche Buchdruckerei, 1898, S. 5.

[8] Knirim, V., Buchholtz, F. (sostaviteli). Selskohozajstvennoje otdelenije Rizhskovo politehnicheskovo instituta za 50 let ego sushhestvovaniya (1862-1912). In: Izvestija i trudi Selskohozajstvennovo otdelenija Rizhskovo politehnicheskovo instituta. Riga: Gekker, 1915, tom 1, vipusk $1 / 2$, s. 40-41.

[9] Rīgas Politehnikums 1862.-1919. g. Album Academicum (1912.-1919. g.). Rīga: LU Studentu grāmatnīcas izdevums, 1938, 22. lpp.

[10] Knirim, V. ., Buchholtz, F. (sostaviteli). Selskohozajstvennoje otdelenije Rizhskovo politehnicheskovo instituta za 50 let ego sushhestvovaniya (1862-1912). In: Izvestija i trudi Selskohozajstvennovo otdelenija Rizhskovo politehnicheskovo instituta. Riga: Gekker, 1915, tom 1, vipusk 1/2, s. 41. 
[11] Zigmunde, A. Pedagogiskā darbība. Rīgas politehnikumā un Rīgas Politehniskajā institūtā (1862-1919). Rīga: RaKa, 2008. 95. lpp.

[12] Knieriem, W., von. Meine Lebenserinnerungen. Riga, 1931, S. 1-32.

[13] Izvestija i trudi Selskohozajstvennovo otdelenija Rizhskovo politehnicheskovo instituta. Riga: Gekker, 1915-1916.

[14] Knieriem, W., von. Meine Lebenserinnerungen. Riga, 1931, S. 13-14.

[15] Knirim, V., Buchholtz, F. (sostaviteli). Selskohozajstvennoje otdelenije Rizhskovo politehnicheskovo instituta za 50 let ego sushhestvovaniya (1862-1912). In: Izvestija i trudi Selskohozajstvennovo otdelenija Rizhskovo politehnicheskovo instituta. Riga: Gekker, 1915, tom 1, vipusk 1/2, s. 12 .

[16] Fjodors Buholcs (20. gadsimta sākums). RTU IVPC VM.

[17] LVVA 7175. f., 1. apr., 91. l.

[18] Vimba, E. Botāniḳim, mikologam Fjodoram Buholcam - 125. Dabas un vēstures kalendārs 1998. gadam. Rīga: Zinātne, 1997, 257.-259. lpp.

[19] Izvestija i trudi Selskohozajstvennovo otdelenija Rizhskovo politehnicheskovo instituta. Riga: Gekker, 1915, tom 1, vipusk 1/2, s. 1.

[20] Knieriem, W. J. K., von. Meine Lebenserinnerungen. Riga, 1931, S. 17.

[21] Knirim, V.(sostavitel). Selsko-hozajstvennij kalendar 1911. Riga: Kimmel, 1910, 192 str.

[22] Nikonov, A. A. Spiral mnogovekovoj drami: agrarnaja nauka i politika Rossii (XVIII-XX vv.). Moskva: Entsiklopediya rossijskikh dereven', 1995, s. 112.

[23] Meshherskij I. I. Novoe polozhenie o sel'skokhozyajstvennom obrazovanii i ego primenenie. Sankt-Peterburg: tip. V. F. Kirshbauma, 1905, 189 str.

[24] Kupffer, R. K. Aus der jüngsten Vergangenheit des Rigaschen Polytechischen Instituts: Materialien zur Geschichte des akademischen Lebens in den Jahren 1896 bis 1906. Riga: Löffler, 1906, S. 160.

[25] LNA LVVA 7175. f., 1. apr., 3. 1, 2. lp.

[26] Knieriem, W. Die landwirtschaftliche Abteilung, speziell die Lehr- und Versuchsfarm Peterhof, am Rigaschen Polytechnikum. In: Festschrift zum fuenfzigjaehrigen Jubilaeum des Rigaschen Polytechnischen Instituts 1862-1912. Riga: W. F. Haecker, 1912, S. 148-149.

[27] Knirim, V. fon., Pohl, K. Otchet o deyatel'nosti i sostoyanii opytnoj fermy «Petergof» za 1912/13 god. In: Izvestija i trudi Selskohozajstvennovo otdelenija Rizhskovo politehnicheskovo instituta. Riga: Gekker, 1915, tom 1, vipusk 1/2, s. 75-94.

[28] Knirim, W., Buchholtz, F. (sostaviteli). Selskohozajstvennoje otdelenije Rizhskovo politehnicheskovo instituta za 50 let ego sushhestvovaniya (1862-1912). In: Izvestija i trudi Selskohozajstvennovo otdelenija Rizhskovo politehnicheskovo instituta. Riga: Gekker, 1915, tom 1, vipusk $1 / 2$, s. 9.

[29] Izvestija i trudi Selskohozajstvennovo otdelenija Rizhskovo politehnicheskovo instituta. Riga: Gekker, 1915, tom 2, vipusk. 1/2, s. 15.

[30] LVVA 7175. f., 1. apr., 7139. 1., 108. lp.

[31] Izvestija i trudi Selskohozajstvennovo otdelenija Rizhskovo politehnicheskovo instituta. Riga: Gekker, 1916, volumen III, vipusk 2, 222 str. 
[32] LVVA 7175. f., 1. apr., 7139., 7140.l.

[33] Augstākās tehniskās izglītības vēsture Latvijā. Rīgas Politehnikums. Rìgas Politehniskais institūts. 1862-1919. Rīga: RTU, 2002, 95.-96. lpp.

[34] [Ferle, Fr.]. Professor Dr. Woldemar v. Knieriem. Rigasche Rundschau, 1925, Nr. 101, S. 5.

[35] Knieriem, W., von. Meine Lebenserinnerungen. Riga: Plates, 1931, 32 S.

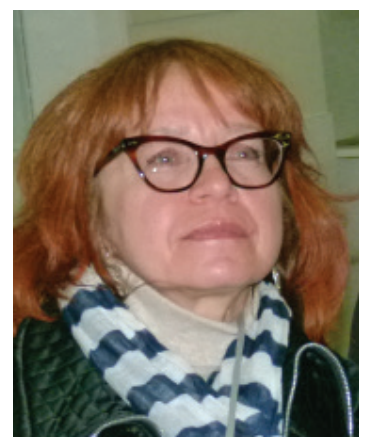

SVETLANA KOVALČUKA is currently a senior researcher with the Institute of Philosophy and Sociology of University of Latvia. She received the degree of cand. of science in Philosophy from the Moscow Institute of Philosophy of the Academy of Science of the USSR (1989) and her PhD from University of Latvia (1992). Her research areas include history of philosophy, Russian philosophy, Russian and Jewish emigrants in the Baltics (1920-1940), Russian and Jewish culture. She has published 3 monographies. Currently she is carrying out her research and is regularly taking part in international conferences in Latvia, Estonia, Russia, Israel as well as publishing her papers in Latvia, Russia, Germany.

E-mail:sv.kovalchuk@gmail.com

Svetlana Kovalčuka

\section{Voldemāra fon Knīrīma ieguldījums Rīgas Politehnikuma un Rīgas Politehniskā institūta mācību un izmēǵinājumu saimniecībā «Pētermuiža»}

Raksts veltīts Rīgas Politehniskā institūta (RPI) direktoram (1906-1916), izcilam organizatoram, zinātnisko darbu autoram profesoram Voldemāram fon Knīrīmam (Woldemar von Knieriem; 1849-1935), kurš devis nozīmīgu ieguldījumu lauksaimniecības zinātnes attīstībā, vadījis RPI Lauksaimniecības nodạ̣u (1903-1906), kā arī mācību un izmēǵinājumu saimniecību «Pētermuiža» (18801915) Olaines tuvumā. Tā kḷuva par paraugsaimniecību ne tikai Baltijas reǵionā, bet visā Krievijas impērijā. Studentiem viṇš sniedza plašas teorētiskās un praktiskās zināšanas lauksaimniecībā, akcentējot praktiskas, zinātniski aprobētas atziṇas par lauksaimniecības platību un muižu apsaimniekošanu. Profesors fon Knīrīms bija Baltijas Tehniskās augstskolas Rīgā rektors (1918), Herdera institūtā Rīgā docētājs (1921-1927). Mūža nogalē viṇš dzīvoja ǵimenes īpašumā Skangaḷu muižā Vidzemē, uzrakstīja atmiṇas par savu dzìvi un vasarās atpūtās un priecājās kopā mazbērniem, viṇu vidū - vēlāko Zviedrijas premjerministru Ūlofu Palmi (Ulof Palme; 1927-1986). V. fon Knīrīms mūžībā devās 1935. gada janvārī, apbedīts Lielajos kapos Rīgā.

Atslēgas vārdi: Voldemārs fon Knīrīms, saimniecība «Pētermuiža», Rīgas Politehniskais institūts, lauksaimniecība. 


\section{Вклад Вольдемара фон Книрима в учебно-опытное имение «Петермуйжа» Рижского политехникума и Рижского политехнического института}

Статья посвящена директору Рижского политехнического института (1906-1916), выдающемуся организатору, автору научных работ, профессору Вольдемару фон Книриму (Woldemar von Knieriem; 1849-1935), который внес значительный вклад в развитие сельскохозяйственной науки, возглавлял Сельскохозяйственное отделение РПИ (1903-1935), a также учебно-испытательное имение «Петермуйжа» (1880-1915) недалеко от Олайне. Оно стало образцовым хозяйством не только в Балтийском регионе, но и во всей Российской империи. В. фон Книрим преподавал студентам обширные теоретические и практические знания в области сельского хозяйства, подчеркнув практические, научно обоснованные знания в области управления сельскохозяйственными угодьями и усадьбами. Профессор фон Книрим был ректором Балтийского технического вуза в Риге (1918), преподавателем в Институте Гердера в Риге (1921-1927). В конце своей жизни он жил в семейной собственности в поместье Скангали в Видземе, писал воспоминания о своей жизни, летом отдыхал и радовался вместе с внуками, среди которых - Улоф Пальме (Ulof Palme; 1927-1986), позднее ставший премьер-министром Швеции. В. фон Книрим умер в январе 1935 года, похоронен на Большом кладбище в Риге.

Ключевые слова: Вольдемар фон Книрим, имение «Петермуйжа», Рижский политехнический институт, сельское хозяйство. 